\title{
Modification at the $\mathrm{C} 9$ position of the marine natural product isoaaptamine and the impact on HIV-1, mycobacterial, and tumor cell activity
}

\author{
Waseem Gula, Nicholas L. Hammond ${ }^{\mathrm{a}}$, Muhammad Yousaf ${ }^{\mathrm{a}}$, John J. Bowling ${ }^{\mathrm{a}}$, Raymond F. \\ Schinazi ${ }^{\mathrm{b}}$, Susan S. Wirtz ${ }^{\mathrm{b}}$, Garcia de Castro Andrews ${ }^{c}$, Carmen Cuevas ${ }^{c}$, and Mark T. \\ Hamann ${ }^{\mathrm{a},}{ }^{\star}$ \\ aDepartment of Pharmacognosy and the National Center for Natural Products Research \\ (NCNPR), University of Mississippi School of Pharmacy, MS 38677, USA \\ bDepartment of Pediatrics, Emory University/VA Medical Center, Decatur Georgia 30033, USA \\ 'Research \& Development, PharmaMar S.A., 28770-Colmenar Viejo, Madrid, Spain
}

\begin{abstract}
As part of an investigation to generate optimized drug leads from marine natural pharmacophores for the treatment of neoplastic and infectious diseases, a series of novel isoaaptamine analogs were prepared by coupling acyl halides to the C9 position of isoaaptamine (2) isolated from the Aaptos sponge. This library of new semisynthetic products was evaluated for biological activity against HIV-1, Mtb, AIDS-OI, tropical parasitic diseases, and cancer. Compound 4 showed potent activity against HIV-1 ( $\left.\mathrm{EC}_{50} 0.47 \mu \mathrm{g} / \mathrm{mL}\right)$, compound 19 proved to possess remarkable activity against Mycobacterium intracellulare with an $\mathrm{IC}_{50}$ and MIC value of 0.15 and $0.31 \mu \mathrm{g} / \mathrm{mL}$, while compounds 4 and 17 possessed anti-leishmanial activity with $\mathrm{IC}_{50}$ values of 0.1 and $0.4 \mu \mathrm{g} / \mathrm{mL}$, respectively. Compounds $\mathbf{1 6}$ and $\mathbf{1 7}$ showed antimalarial activity with $\mathrm{EC}_{50}$ values of 230 and 240 $\mathrm{ng} / \mathrm{mL}$, respectively, and compound $\mathbf{1 4}$ exhibited an $\mathrm{EC}_{50}$ of $0.05 \mu \mathrm{M}$ against the Leukemia cell line K-562.
\end{abstract}

\section{Keywords}

Isoaaptamine derivatives; Anti-cancer leads; Anti-HIV-1 activity; Marine natural products

\section{Introduction}

The development of resistance and the toxicity associated with current chemotherapeutic agents has led to an increasing failure of existing drugs utilized in the treatment of various microbial, viral, and neoplastic disorders. The marine environment, and the unique natural products contained therein, remains a relatively untapped source of possibilities for novel drug development. As seen in Figure 1, the marine natural product aaptamine (1), first

\footnotetext{
*Corresponding author. Tel.: +1 662915 5730; fax: +1 662916 6975; mthamann@ olemiss.edu.

Supplementary data

Supplementary data associated with this article can be found, in the online version, at doi:10.1016/j.bmc.2006.08.042.
} 
isolated by Nakamura, has been reported to have antineoplastic and a-adrenoceptor blocking activity.' The closely related compound isoaaptamine (2) was first isolated by Fedoreev from a sponge in the genus Suberites and later by two other groups from the sponge Aaptos aaptos.' Recently, isoaaptamine (2) was isolated from a sponge belonging to the genus Hymeniacidon. Isoaaptamine (2) has also been reported to be a PKC inhibitor. However, the recent investigation by Pettit et al. of PKC inhibition and tubulin polymerization showed only minimal activity. However, further investigation by this group revealed that inhibition of the S-Phase of the cell cycle may be involved in the observed cytotoxicity which suggests a possible interaction with DNA or topoisomerase. The closely related bis(naphthalimide) derivative DMP 840 (A) has been reported to be a topoisomerase II inhibitor and is currently undergoing phase I clinical trials. Additionally, the analog LU 79553 (B) has shown efficacy in vivo against tumor xenographs. The related acridine anticancer agent $\mathrm{AAC}(\mathbf{C})$ has also been shown to elicit its activity through modulation of topoisomerase II.- Additional SAR investigation suggests a positive correlation between nonelectrostatic binding free energy and anti-cancer potency of acridine derivatives.

Aaptamine, isoaaptamine, and demethylated aaptamine have shown antifouling activity in the zebra mussel assay with $\mathrm{EC}_{50}$ values of $24.2,11.6$, and $18.6 \mu \mathrm{M}$ respectively. Isoaaptamine (2) has shown activity against the protozoan that causes malaria, Plasmodium falciparum, with an $\mathrm{IC}_{50}$ of 1.8 and $0.6 \mu \mathrm{g} / \mathrm{mL}$ for the D6 and W2 clones, respectively. Pettit et al. recently reported dibenzyl aaptamine derivatives with activity against Mycobacterium tuberculosis. Isoaaptamine has been shown to exhibit remarkable activity against cancer cell lines including P-338," (murine lymphocytic leukemia), KB16 (human mouth epidermoid carcinoma), A549 (human lung adenocarcinoma), and HT-29 (human colon adenocarcinoma). The synthesis of aaptamine (1) and isoaaptamine (2) has recently been reported. The first SAR study of these compounds by Shen et al. concluded that the C-9 hydroxyl position was important for cytotoxic activity and acylation causes a decrease in activity. Recently, the studies by Pettit et al." with modifications at the hydroxyl and nitrogen positions of aaptamine have aided to further elucidate the SAR of these unique compounds. Specifically, para substituted phenyl substituents at one or both of the nitrogen positions increased activity.

In order to further investigate the SAR of side-chain attachment at the C9 hydroxyl position of isoaaptamine (2), which is readily available from the sponge Aaptos sp. in gram quantities, a series of analogs was generated. Presented here are 19 derivatives (Table 1) of isoaaptamine (2) generated with various acyl halides coupled at the C9 position of isoaaptamine (2) and their biological activity against a number of pathogens and cancer cell lines.

\section{Results and discussion}

The products 3-21 have been evaluated for activity against malaria, AIDS-OI pathogens, leishmania, cancer, HIV-1, and Mtb. The results from the in vitro assays and preliminary SAR are presented in Tables 2-4. 


\subsection{Anti-HIV-1}

The anti-HIV-1 activity of isoaaptamine $(2,0.6 \mu \mathrm{M})$ and aaptamine $(1.30 \mu \mathrm{M})$ has previously been reported. The structure-activity relationship of fluorine substitution on an indole heterocyclic system has recently been reported to increase the potency of anti-HIV-1 activity. Compounds 5, 6, 7, and 15 contained fluorine at different positions on the phenyl substituent. Substitution of fluorine at the ortho position $\left(7, \mathrm{EC}_{50} 2.1 \mu \mathrm{g} / \mathrm{mL}\right)$, relative to substitution at other positions on the ring, increased activity except where there was adjacent fluorine $\left(\mathbf{6}, \mathrm{EC}_{50} 37.7 \mu \mathrm{g} / \mathrm{mL}\right)$ in the meta position. Substitution of fluorine in the para position $\left(\mathbf{5}, \mathrm{EC}_{50} 10.9 \mu \mathrm{g} / \mathrm{mL} ; \mathbf{1 5}, \mathrm{EC}_{50} 16.6 \mu \mathrm{g} / \mathrm{mL}\right)$ was not as dramatic except where the substituent was a tri-fluorinated $O$-methyl group $\left(\mathbf{1 2}, \mathrm{EC}_{50} 2.3 \mu \mathrm{g} / \mathrm{mL}\right)$. The position of fluorine substitution on the phenyl ring appears to be the most important aspect for antiHIV-1 activity. Methyl substitution at the ortho, para, and meta positions (3, 11, and 16) reflects the same pattern seen in the fluorinated derivatives with highest activity in ortho (3, $\mathrm{EC}_{50} 1.3 \mu \mathrm{g} / \mathrm{mL}$ ) substitution. Substitution at the para position with carbon chains of varying length shows a dramatic increase in activity with ethyl $\left(\mathbf{4}, \mathrm{EC}_{50} 0.47 \mu \mathrm{g} / \mathrm{mL}\right)$ having better activity than methyl $\left(\mathbf{1 6}, \mathrm{EC}_{50} 9.2 \mu \mathrm{g} / \mathrm{mL}\right)$ and a decrease as the chain is lengthened (13, $\mathrm{EC}_{50} 3.8 \mu \mathrm{g} / \mathrm{mL} ; 14, \mathrm{EC}_{50} 18.8 \mu \mathrm{g} / \mathrm{mL}$ ). Taking these results into consideration, short chain para substitution provides the best structure for anti-HIV-1 activity in this series of compounds.

\subsection{AIDS opportunistic pathogens}

Isoaaptamine (2) alone did not show toxic activity $\left(\mathrm{IC}_{50} \leq 15 \mu \mathrm{g} / \mathrm{mL}\right.$ ) against any of the tested microbes. However, several derivatives $(\mathbf{4}, \mathbf{1 3}, \mathbf{1 4}$, and 17) showed significant activity against Mycobacterium intracellulare with alkyl para substitution on the phenyl ring being the dominant pattern. Most interesting was the remarkable activity of compound $\mathbf{1 9}\left(\mathrm{IC}_{50}\right.$ $0.2 \mu \mathrm{g} / \mathrm{mL}$, MIC $0.3 \mu \mathrm{g} / \mathrm{mL}$ ) against $M$. intracellulare being more active than ciprofloxacin ( $\mathrm{IC}_{50} 0.3 \mu \mathrm{g} / \mathrm{mL}$, MIC $1.3 \mu \mathrm{g} / \mathrm{mL}$ ). Compound 19, deviating from the aforementioned pattern, consists of a 17 carbon acyl ester chain with an unsaturation between $\mathrm{C} 9^{\prime}$ and $\mathrm{C} 10^{\prime}$.

Tuberculosis, malaria, and leishmaniasis-Isoaaptamine (2) did not show activity against Mycobacterium tuberculosis. However, the derivative (21) was active with $\mathrm{IC}_{50}$ values of $41.03 \mu \mathrm{g} / \mathrm{mL}$. There was no evident congruence in the derivative structure and the activity reported.

The activity of isoaaptamine $\left(2, \mathrm{IC}_{50} 0.68 \mu \mathrm{g} / \mathrm{mL}\right)$ was more active than both pentamidine ( $\mathrm{IC}_{50} 1.6 \mu \mathrm{g} / \mathrm{mL}$ ) and amphotericin B ( $\mathrm{IC}_{50} 1.1 \mu \mathrm{g} / \mathrm{mL}$ ) against Leishmania donovani. Modification of isoaaptamine (2) resulted in an increase in activity with the most active derivative $4\left(\mathrm{IC}_{50} 0.1 \mu \mathrm{g} / \mathrm{mL}\right)$ containing a para ethyl-substituted phenyl ring and $\mathbf{1 7}\left(\mathrm{IC}_{50}\right.$ $0.4 \mu \mathrm{g} / \mathrm{mL}$ ) containing a para tert-butyl-substituted phenyl ring. Substitution of a group longer than two carbons in the para position decreases the activity against Leishmania. Isoaaptamine (2) shows remarkable activity against the $\mathrm{W} 2$ clone and mild activity against the D6 clone of $P$. falciparum prior to modification $(380,1100 \mathrm{ng} / \mathrm{mL}$, respectively). All modifications had a negative impact on the activity against the W2 clone. However, an increase in D6 activity of many of the derivatives was observed $(\mathbf{4}, \mathbf{5}, \mathbf{1 0}-\mathbf{1 7}, \mathbf{2 0}$, and 21) with para substitution on the phenyl ring of short carbon chains for compounds $4\left(\mathrm{IC}_{50} 330\right.$ 
$\mathrm{ng} / \mathrm{mL}), 16\left(\mathrm{IC}_{50} 230 \mathrm{ng} / \mathrm{mL}\right)$, and $17\left(\mathrm{IC}_{50} 240 \mathrm{ng} / \mathrm{mL}\right)$ being the most potent. A decrease in activity corresponding to extension of the chain was also observed. Although additional derivatives showed activity, no other obvious patterns were evident.

\subsection{Cancer cell cytotoxicity}

Isoaaptamine (2) has shown remarkable activity against a range of different cancer cell lines with activity against the murine leukemia cell line P388 as low as $0.28 \mu \mathrm{g} / \mathrm{mL}$. All 21 compounds were evaluated against 14 different cancer cell lines, many of which can be found in Table 4 . The compounds found to have broad activity against the tested cell lines $(4,10,12-14,16,17,19$, and 20) contained para substituted phenyl rings. Most notable were the activities of $\mathbf{1 3}\left(\mathrm{GI}_{50} 1.66 \mu \mathrm{M}\right), \mathbf{1 4}\left(\mathrm{GI}_{50} 0.05 \mu \mathrm{M}\right)$, and $\mathbf{1 7}\left(\mathrm{GI}_{50} 1.9 \mu \mathrm{M}\right)$ against the leukemia cell line K-562. Compound 14 was substituted with a 5 carbon chain at the para position while compounds $\mathbf{1 3}$ and $\mathbf{1 7}$ were substituted with a 4 carbon chain and a $t$ butyl group, respectively. A decrease in activity was observed with a methyl $(\mathbf{1 6}, 5.8 \mu \mathrm{M})$ or an ethyl $(4,6.0 \mu \mathrm{M})$ substituent at the para position.

The prevalence of para substitution of a phenyl ring attached via an ester linkage to the C9 hydroxyl position of isoaaptamine (2) appears to be the underlying SAR evident in the data presented in this paper. The substituent at the para position determined the selectivity toward the target of interest. Substitution of a phenyl ester moiety at the C9 position of isoaaptamine (2) was more effective than the acylation previously reported at this position by Shen et al. A further point of observation reveals the congruence of the attachment of para substituted cyclic moieties in this group of compounds with and overall increase in activity. This observation reflects the results found in the present study and those previously published by Pettit et al.

In conclusion, this is the first reported SAR investigation for anti-HIV-1 activity of the aaptamine alkaloids thus far. In addition, we are now able to report several optimized potential antitumor (12-14, and 17) and anti-infective leads $(4,13,14,17$, and 19), suggesting that further investigations of this class of marine natural products maybe fruitful. Natural products have been credited with as many as $75 \%$ of the treatments of infectious diseases and $60 \%$ of treatments for cancer. However only 5-6\% represent the unmodified natural product indicating the importance of optimizing novel marine natural product structural classes with reasonable drug-like properties.

\section{Experimental}

\subsection{General}

1D and 2D NMR spectra were recorded on a Bruker Avance DRX-400 spectrometer. Chemical shift $(\delta)$ values expressed in parts per million (ppm) are referenced to the residual solvent signals with resonances at $\delta_{\mathrm{H}} / \delta_{\mathrm{C}} 7.26 / 77.00\left(\mathrm{CDCl}_{3}\right)$. ESI-FTMS analyses were measured on a Bruker-Magnex BioAPEX 30es ion cyclotron HR HPLC-FT spectrometer by direct injection into an electrospray interface. TLC was performed on aluminum sheets ( $\mathrm{Si}$ gel $60 \mathrm{~F}_{254}$, Merck KGaA, Germany) with an acetone/hexane (80:20) solvent system. All acyl halides were purchased from Sigma-Aldrich, USA.

Bioorg Med Chem. Author manuscript; available in PMC 2016 June 30. 
Isoaaptamine (2) $(150 \mathrm{mg}, 0.657 \mathrm{mmol})$ was dissolved in dry methylene chloride $(2 \mathrm{~mL})$ at $0{ }^{\circ} \mathrm{C}, 0.5 \mathrm{~mL}$ of tri-ethyl amine was added, and the reaction mixture was stirred for $30 \mathrm{~min}$. An excess of the acyl halide was added dropwise over a period of $15 \mathrm{~min}$. The reaction was allowed to stir at $0{ }^{\circ} \mathrm{C}$ for $30 \mathrm{~min}$, slowly warmed to room temperature, and the progress was monitored on TLC. The reaction was stopped when the TLC showed the reaction was completed (2-24 h). The residue was fractionated on silica gel G254 $2000 \mu \mathrm{m}$ using MeOH/ $\mathrm{CHCl}_{3}$ (80:20) and yielded products of various colors for compounds 3-21.

3.1.1. 9-0-2-methylbenzoylisoaaptamine (3)—Brownish amorphous solid; ${ }^{1} \mathrm{H}$ and ${ }^{13} \mathrm{C} \mathrm{NMR}\left(\mathrm{CDCl}_{3}\right)$ data see Table 5; ESI-MS $\mathrm{m} / z 347\left(\mathrm{M}^{+}, 100\right)$. High resolution EIMS calculated for $\mathrm{C}_{21} \mathrm{H}_{18} \mathrm{~N}_{2} \mathrm{O}_{3}\left(\mathrm{M}^{+}\right) \mathrm{m} / z$ 347.1396, observed $\mathrm{m} / z$ 347.1396.

3.1.2. 9-O-4-ethylbenzoylisoaaptamine (4)—Brownish powder; ${ }^{1} \mathrm{H}$ and ${ }^{13} \mathrm{CNMR}\left(\mathrm{CDCl}_{3}\right)$ data see Table 5; ESI-MS $\mathrm{m} / z 361\left(\mathrm{M}^{+}, 100\right)$. High resolution EI-MS calculated for $\mathrm{C}_{22} \mathrm{H}_{20} \mathrm{~N}_{2} \mathrm{O}_{3}\left(\mathrm{M}^{+}\right) \mathrm{m} / z 361.1552$, observed $\mathrm{m} / z 361.1551$.

3.1.3. 9-O-4-fluorobenzoylisoaaptamine (5)—Yellow amorphous solid; ${ }^{1} \mathrm{H}$ and ${ }^{13} \mathrm{C}$ NMR $\left(\mathrm{CDCl}_{3}\right)$ data see Table 5; ESI-MS $\mathrm{m} / z 351\left(\mathrm{M}^{+}, 100\right)$. High resolution EI-MS calculated for $\mathrm{C}_{20} \mathrm{H}_{15} \mathrm{~N}_{2} \mathrm{O}_{3} \mathrm{~F}\left(\mathrm{M}^{+}\right) \mathrm{m} / z$ 351.1145, observed $\mathrm{m} / z$ 351.1145.

3.1.4. 9-0-2,3-difluorobenzoylisoaaptamine (6)—Brownish amorphous solid; ${ }^{1} \mathrm{H}$ and ${ }^{13} \mathrm{C} \mathrm{NMR}\left(\mathrm{CDCl}_{3}\right)$ data see Table 6; ESI-MS $\mathrm{m} / z 369\left(\mathrm{M}^{+}, 100\right)$. High resolution EIMS calculated for $\mathrm{C}_{20} \mathrm{H}_{14} \mathrm{~N}_{2} \mathrm{O}_{3} \mathrm{~F}_{2}\left(\mathrm{M}^{+}\right) \mathrm{m} / z$ 369.1051, observed $\mathrm{m} / z 369.1059$.

3.1.5. 9-0-2,5-difluorobenzoylisoaaptamine (7)—Reddish brown amorphous solid; ${ }^{1} \mathrm{H}$ and ${ }^{13} \mathrm{C}$ NMR $\left(\mathrm{CDCl}_{3}\right)$ data see Table 6; ESI-MS $\mathrm{m} / z 369\left(\mathrm{M}^{+}, 100\right)$. High resolution EI-MS calculated for $\mathrm{C}_{20} \mathrm{H}_{14} \mathrm{~N}_{2} \mathrm{O}_{3} \mathrm{~F}_{2}\left(\mathrm{M}^{+}\right) \mathrm{m} / z$ 369.1051, observed $\mathrm{m} / z$ 369.1054 .

3.1.6. 9-O-diethylcarbamoylisoaaptamine (8)—Dark red amorphous solid; ${ }^{1} \mathrm{H}$ and ${ }^{13} \mathrm{C}$ NMR $\left(\mathrm{CDCl}_{3}\right)$ data see Table 6; ESI-MS $\mathrm{m} / z 328\left(\mathrm{M}^{+}, 100\right)$. High resolution EIMS calculated for $\mathrm{C}_{18} \mathrm{H}_{21} \mathrm{~N}_{3} \mathrm{O}_{3}\left(\mathrm{M}^{+}\right) \mathrm{m} / z$ 328.1661, observed $\mathrm{m} / z 328.1653$.

3.1.7. 9-O-2-(thiophenyl)acetylisoaaptamine (9)—Greenish black amorphous solid; ${ }^{1} \mathrm{H}$ and ${ }^{13} \mathrm{C}$ NMR $\left(\mathrm{CDCl}_{3}\right)$ data see Table 7; ESI-MS $\mathrm{m} / z 379\left(\mathrm{M}^{+}, 100\right)$. High resolution EI-MS calculated for $\mathrm{C}_{21} \mathrm{H}_{18} \mathrm{~N}_{2} \mathrm{O}_{3} \mathrm{~S}\left(\mathrm{M}^{+}\right) \mathrm{m} / z$ 379.1116, observed $\mathrm{m} / z$ 379.1113.

3.1.8. 9-0-4-chloromethylbenzoyl isoaaptamine (10)—Dark yellow amorphous solid; ${ }^{1} \mathrm{H}$ and ${ }^{13} \mathrm{C}$ NMR $\left(\mathrm{CDCl}_{3}\right)$ data see Table 7; ESI-MS $\mathrm{m} / z 381\left(\mathrm{M}^{+}, 100\right)$. High resolution EI-MS calculated for $\mathrm{C}_{21} \mathrm{H}_{17} \mathrm{~N}_{2} \mathrm{O}_{3} \mathrm{Cl}\left(\mathrm{M}^{+}\right) \mathrm{m} / z$ 381.1006, observed $\mathrm{m} / z$ 381.1000 .

3.1.9. 9-0-3-methylbenzoylisoaaptamine (11)—Brown amorphous solid; ${ }^{1} \mathrm{H}$ and ${ }^{13} \mathrm{C}$ NMR $\left(\mathrm{CDCl}_{3}\right)$ data see Table 7; ESI-MS $\mathrm{m} / z 347\left(\mathrm{M}^{+}, 100\right)$. High resolution EIMS calculated for $\mathrm{C}_{21} \mathrm{H}_{18} \mathrm{~N}_{2} \mathrm{O}_{3}\left(\mathrm{M}^{+}\right) \mathrm{m} / z$ 347.1396, observed $\mathrm{m} / z$ 347.1391. 
3.1.10. 9-0-4-trifluoromethoxybenzoylisoaaptamine (12)-Yellowish brown amorphous solid; ${ }^{1} \mathrm{H}$ and ${ }^{13} \mathrm{C}$ NMR $\left(\mathrm{CDCl}_{3}\right)$ data see Table 8; ESI-MS $\mathrm{m} / z 417\left(\mathrm{M}^{+}, 100\right)$. High resolution EI-MS calculated for $\mathrm{C}_{21} \mathrm{H}_{15} \mathrm{~N}_{2} \mathrm{O}_{4} \mathrm{~F}_{3}\left(\mathrm{M}^{+}\right) \mathrm{m} / z$ 417.1062, observed $\mathrm{m} / z$ 417.1069.

3.1.11. 9-0-4-butylbenzoylisoaaptamine (13)—Brown amorphous solid; ${ }^{1} \mathrm{H}$ and ${ }^{13} \mathrm{C}$ NMR $\left(\mathrm{CDCl}_{3}\right)$ data see Table 8; ESI-MS $\mathrm{m} / z 389\left(\mathrm{M}^{+}, 100\right)$. High resolution EIMS calculated for $\mathrm{C}_{24} \mathrm{H}_{24} \mathrm{~N}_{2} \mathrm{O}_{3}\left(\mathrm{M}^{+}\right) \mathrm{m} / z$ 389.1865, observed $\mathrm{m} / z 389.1875$.

3.1.12. 9-0-4-pentylbenzoylisoaaptamine (14)—Brown amorphous solid; ${ }^{1} \mathrm{H}$ and ${ }^{13} \mathrm{C}$ NMR $\left(\mathrm{CDCl}_{3}\right)$ data see Table 8; ESI-MS $\mathrm{m} / z 403\left(\mathrm{M}^{+}, 100\right)$. High resolution EIMS calculated for $\mathrm{C}_{25} \mathrm{H}_{26} \mathrm{~N}_{2} \mathrm{O}_{3}\left(\mathrm{M}^{+}\right) \mathrm{m} / z$ 403.2022, observed $\mathrm{m} / z$ 403.2009.

3.1.13. 9-0-3,4-difluorobenzoylisoaaptamine (15)—Greenish powder; ${ }^{1} \mathrm{H}$ and ${ }^{13} \mathrm{C}$ NMR $\left(\mathrm{CDCl}_{3}\right)$ data see Table 9; ESI-MS $\mathrm{m} / z 369\left(\mathrm{M}^{+}, 100\right)$. High resolution EI-MS calculated for $\mathrm{C}_{20} \mathrm{H}_{14} \mathrm{~N}_{2} \mathrm{O}_{3} \mathrm{~F}_{2}\left(\mathrm{M}^{+}\right) \mathrm{m} / z$ 369.1051, observed $\mathrm{m} / z$ 369.1065.

3.1.14. 9-0-4-methylbenzoylisoaaptamine (16)—Brown amorphous solid; ${ }^{1} \mathrm{H}$ and ${ }^{13} \mathrm{C}$ NMR $\left(\mathrm{CDCl}_{3}\right)$ data see Table 9; ESI-MS $\mathrm{m} / z 347\left(\mathrm{M}^{+}, 100\right)$. High resolution EIMS calculated for $\mathrm{C}_{21} \mathrm{H}_{18} \mathrm{~N}_{2} \mathrm{O}_{3}\left(\mathrm{M}^{+}\right) \mathrm{m} / z$ 347.1396, observed $\mathrm{m} / z$ 347.1378.

3.1.15-9-O-4-tert-butylbenzoylisoaaptamine (17). brown amorphous solid; ${ }^{1} \mathrm{H}$ and ${ }^{13} \mathrm{C}$ NMR $\left(\mathrm{CDCl}_{3}\right)$ data see Table 9; ESI-MS $\mathrm{m} / z 389\left(\mathrm{M}^{+}, 100\right)$. High resolution EIMS calculated for $\mathrm{C}_{24} \mathrm{H}_{24} \mathrm{~N}_{2} \mathrm{O}_{3}\left(\mathrm{M}^{+}\right) \mathrm{m} / z$ 389.1865, observed $\mathrm{m} / z 389.1877$.

3.1.16. 9-0-1-(pyrrolidine)carbonylisoaaptamine (18)—Pale orange oil; ${ }^{1} \mathrm{H}$ and ${ }^{13} \mathrm{C}$ NMR $\left(\mathrm{CDCl}_{3}\right)$ data see Table 10; ESI-MS $\mathrm{m} / z 326\left(\mathrm{M}^{+}, 100\right)$. High resolution EIMS calculated for $\mathrm{C}_{18} \mathrm{H}_{19} \mathrm{~N}_{3} \mathrm{O}_{3}\left(\mathrm{M}^{+}\right) \mathrm{m} / z$ 326.1505, observed $\mathrm{m} / \mathrm{z} 326.1501$.

3.1.17. 9-O-Z-oleoylisoaaptamine (19)—Brown amorphous solid; ${ }^{1} \mathrm{H}$ and ${ }^{13} \mathrm{C}$ NMR $\left(\mathrm{CDCl}_{3}\right)$ data see Table 10; ESI-MS $\mathrm{m} / z 493\left(\mathrm{M}^{+}, 100\right)$. High resolution EIMS calculated for $\mathrm{C}_{31} \mathrm{H}_{44} \mathrm{~N}_{2} \mathrm{O}_{3}\left(\mathrm{M}^{+}\right) \mathrm{m} / z$ 493.3430, observed $\mathrm{m} / z$ 493.3412.

3.1.18. 9-O-4-cyanobenzoylisoaaptamine (20)—Brownish amorphous solid; ${ }^{1} \mathrm{H}$ and ${ }^{13} \mathrm{C}$ NMR $\left(\mathrm{CDCl}_{3}\right)$ data see Table 10; ESI-MS $\mathrm{m} / z 358\left(\mathrm{M}^{+}, 100\right)$. High resolution EIMS calculated for $\mathrm{C}_{21} \mathrm{H}_{15} \mathrm{~N}_{3} \mathrm{O}_{3}\left(\mathrm{M}^{+}\right) \mathrm{m} / z$ 358.1192, observed $\mathrm{m} / z$ 358.1192.

3.1.19. 9-0-3-methoxybenzoylisoaaptamine (21)—Brown amorphous solid; ${ }^{1} \mathrm{H}$ and ${ }^{13} \mathrm{C} \mathrm{NMR}\left(\mathrm{CDCl}_{3}\right)$ data see Table 11; ESI-MS $\mathrm{m} / z 363\left(\mathrm{M}^{+}, 100\right)$. High resolution EIMS calculated for $\mathrm{C}_{21} \mathrm{H}_{18} \mathrm{~N}_{2} \mathrm{O}_{4}\left(\mathrm{M}^{+}\right) \mathrm{m} / z 363.1219$, observed $\mathrm{m} / z 363.1224$.

\section{Supplementary Material}

Refer to Web version on PubMed Central for supplementary material. 


\section{Acknowledgments}

We are indebted to S. Wahyuono and A. Mursyidi from Gadjah Mada University, Indonesia, for assistance with sample collection, J. Trott for in vitro malaria assays, B. Tekwani for leishmania assays, S. Franzblau and F. Zhang for Mtb assays, and P. Tharnish for anti-HIV-1 assays. We are also indebted to S. Sanders and B. Smiley, from the National Center for Natural Products Research, for bioassays. We are grateful to A. Holley, A. Murphy, and J. Fiechtl for their help in table preparation and J. Mustafa for valuable suggestions and discussions. This work was supported by NIH (R01A136596, KO2AI01502), Pharma-Mar, R.F.S. is supported by the Emory University Center for AIDS Research and Department of Veterans Affairs. This investigation was conducted in a facility constructed with support from Research Facilities Improvement Program (C06 RR-14-503-01) from the National Center for Research Resources (NIH).

\section{References and notes}

1. Nakamura H, Kobayash J, Ohizumi Y, Hirata Y. Tetrahedron Lett. 1982; 23:5555-5558.

2. Ohizumi Y, Kajiwara A, Nakamura H, Kobayashi J. J Pharm Pharmacol. 1984; 36:785-786. [PubMed: 6150989]

3. Fedoreev S, Prokofeva N, Denisenko V, Rebachuk N. Khim Farm Zh. 1988; 22:943.

4. Kashman Y, Rudi A, Hirsh S, Isaacs S, Green D, Blasberger D, Carmely S. New J Chem. 1990; 14:729-740.

5. Shen Y, Chein C, Hsieh P, Duh C. Taiwan Shuichan Xuehuikan. 1997; 24:117.

6. Pettit GR, Hoffmann H, McNulty J, Higgs KC, Murphy A, Molloy DJ, Herald DL, Williams MD, Pettit RK, Doubek DL, Hooper JNA, Albright L, Schmidt JM, Chapuis J, Tackett LP. J Nat Prod. 2004; 67(3):506-509. [PubMed: 15043446]

7. Patil, A.; Westley, J.; Mattern, M.; Freyer, A.; Hofmann, G. PCT Int Appl. WO 95/0584. Mar. 1995

8. Pettit GR, Hoffmann H, Herald DL, McNulty J, Murphy A, Higgs KC, Hamel E, Lewin NE, Pearce LV, Blumberg PM, Pettit RK, Knight JC. J Org Chem. 2004; 69:2251-2256. [PubMed: 15049616]

9. Nitiss J, Zhou J, Rose A, Hsiung Y, Gale K, Osheroff N. Biochemistry. 1998; 37:3078-3085. [PubMed: 9485461]

10. O’Reilly S, Baker S, Sartorius S, Rowinsky E, Finizio M, Lubiniecki G, Grochow L, Gray J, Pieniaszek H, Donehower R. Ann Oncol. 1998; 9:101-104. [PubMed: 9541690]

11. Bousquet P, Brana M, Conlon D, Fitzgerald K, Perron D, Cocchiaro C, Miller R, Moran M, George J, Qian X. Cancer Res. 1995; 55:1176-1180. [PubMed: 7867004]

12. Atwell G, Cain B, Baguley B, Finlay G, Denny W. J Med Chem. 1984; 27:1481-1485. [PubMed: 6492078]

13. Denny W, Wakelin L. Cancer Res. 1986; 46:1719-1725.

14. Finlay G, Riou J, Baguley B. Eur J Cancer. 1996; 32:708-714. [PubMed: 8695277]

15. Hutchins R, Crenshaw J, Graves D, Denny W. Biochemistry. 2003; 42:13754-13761. [PubMed: 14622022]

16. Diers JA, Pennaka HK, Peng J, Bowling JJ, Duke SO, Hamann MT. J Nat Prod. 2004; 67:21172120. [PubMed: 15620267]

17. Pettit GR, Hoffmann H, Herald DL, Blumberg PM, Hamel E, Schmidt JM, Chang Y, Pettit RK, Lewin NE, Pearce LV. J Med Chem. 2004; 47(7):1775-1782. [PubMed: 15027869]

18. Sugino E, Choshi T, Hibino S. Heterocycles. 1999; 50:543.

19. Walz A, Sundberg R. J Org Chem. 2000; 65:8001. [PubMed: 11073610]

20. Shen YC, Lin TT, Sheu JH, Duh CY. J Nat Prod. 1999; 62:1264-1267. [PubMed: 10514310]

21. Gochfeld D, El Sayed K, Yousaf M, Hu J, Bartyzel P, Dunbar D, Wilkins S, Zjawiony J, Schinazi R, Wirtz S, Tharnish P, Hamann M. Mini Rev Med Chem. 2003; 3:401-424. [PubMed: 12769693]

22. Wang T, Zhang Z, Wallace O, Deshpande M, Fang H, Yang Z, Zadjura L, Tweedie D, Huang S, Zhao F, Ranadive S, Robinson B, Gong Y, Ricarrdi K, Spicer T, Deminie C, Rose R, Wang H, Blair W, Shi P, Lin P, Colonno R, Meanwell N. J Med Chem. 2003; 46:4236-4423. [PubMed: 13678401]

23. Newman DJ, Cragg GM, Snader KM. J Nat Prod. 2003; 66:1022-1037. [PubMed: 12880330] 

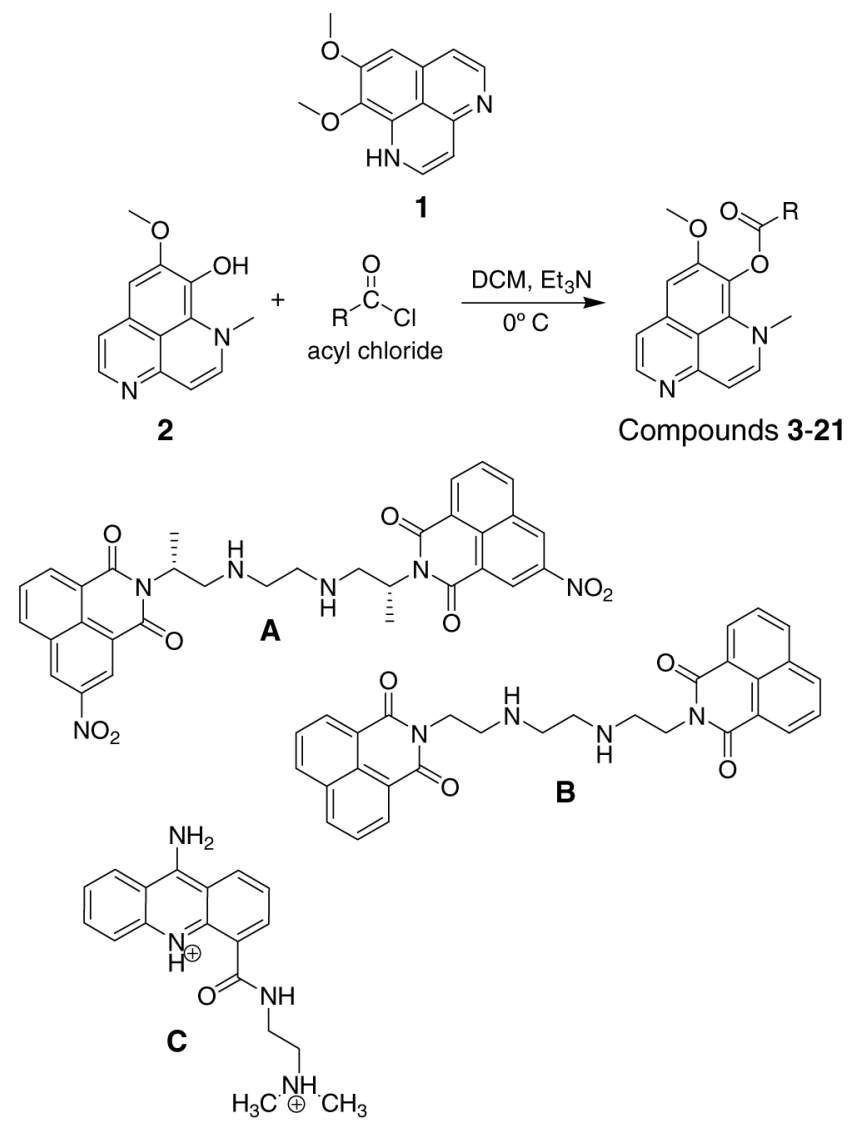

Figure 1.

Aaptamine related structures. 
Table 1

Isoaaptamine derivatives Entry Product Yield (\%)

Entry Product

Yield (\%)

3

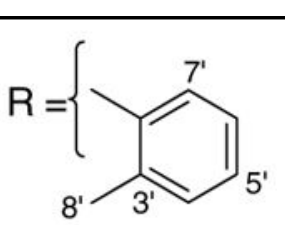

89

4

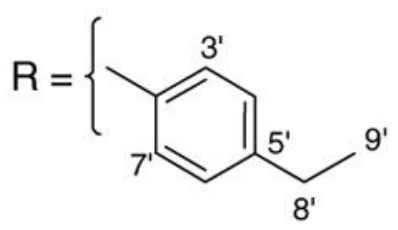

91

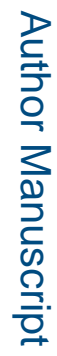

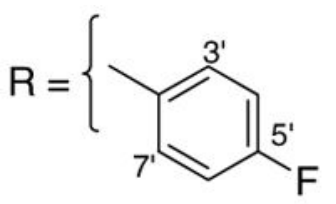

6<smiles>[R]C(C)Cc1[c]ccc(F)c1F</smiles>

85

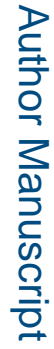

7<smiles>[R]C(C)(C)C1=C(F)[Se]C=C(F)[Se]1</smiles>

8<smiles>[R]C(C)N([CH])C[Hg]</smiles>

85

84<smiles>[R]C(C)(C)CSc1ccccc1</smiles>

91

90

Bioorg Med Chem. Author manuscript; available in PMC 2016 June 30. 


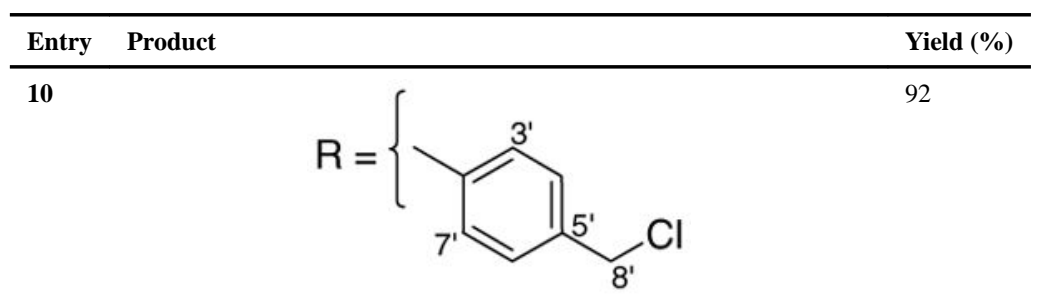

11

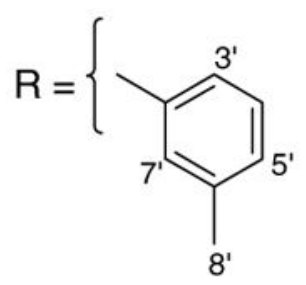

94

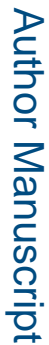

12

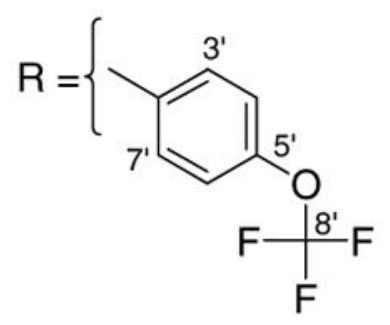

82

13

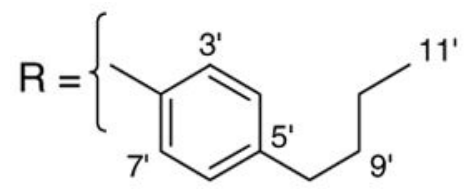

93

14

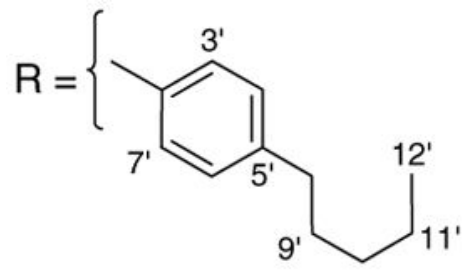

94<smiles></smiles>

83

Bioorg Med Chem. Author manuscript; available in PMC 2016 June 30. 

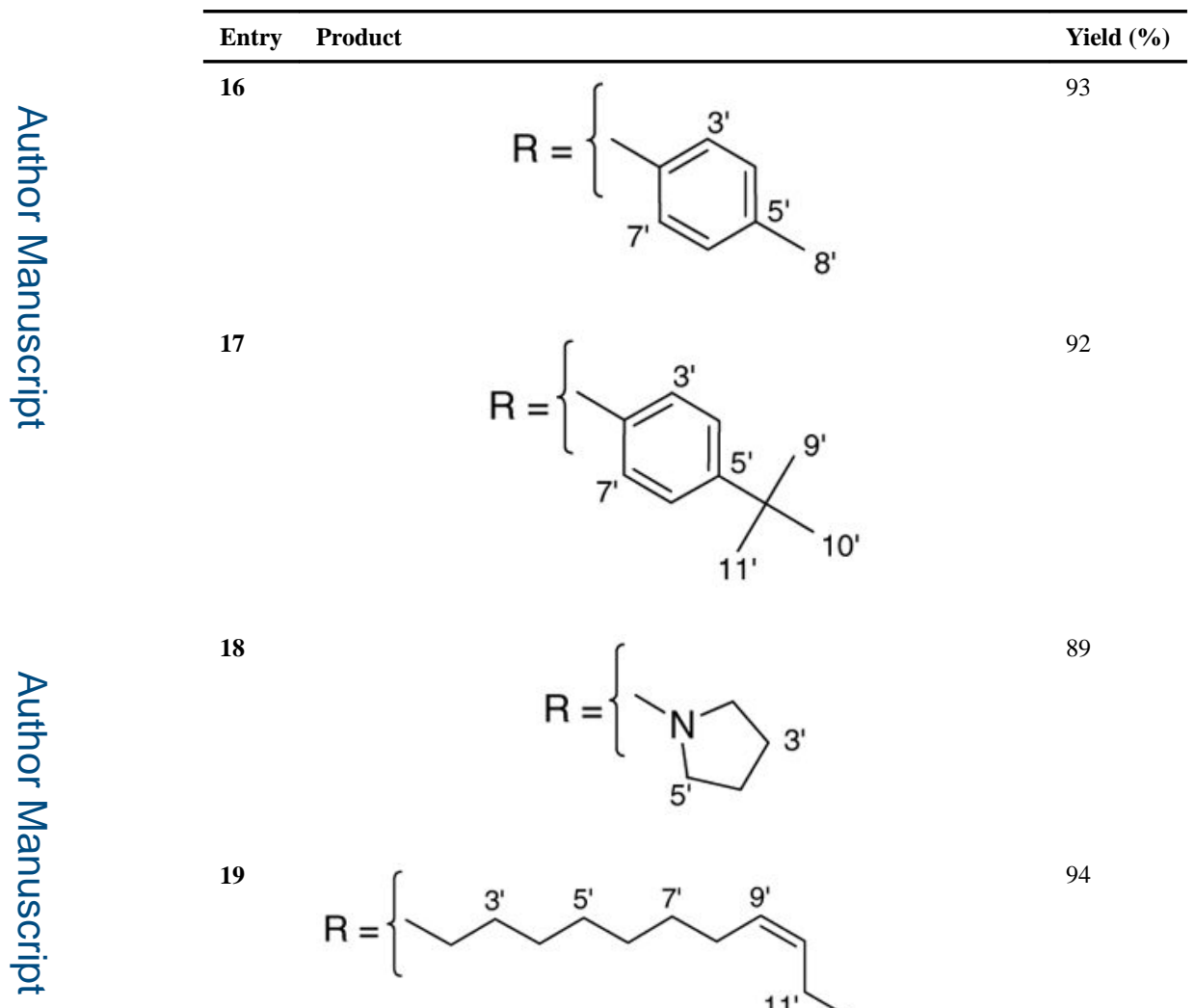

18

$$
R=\left\{N_{5^{\prime}}\right.
$$

89

19

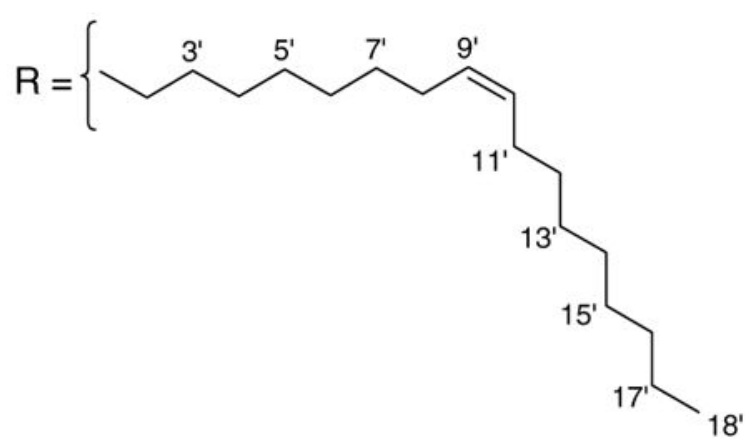

20

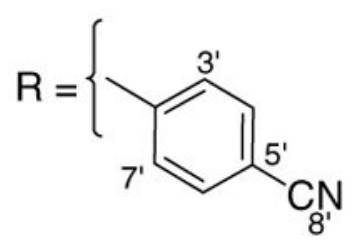

94

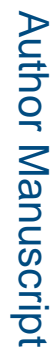

86

21

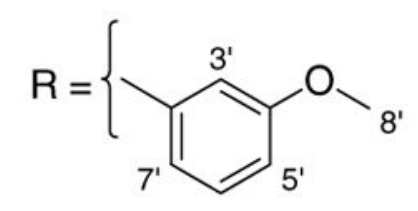

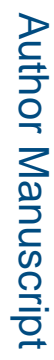

Bioorg Med Chem. Author manuscript; available in PMC 2016 June 30. 


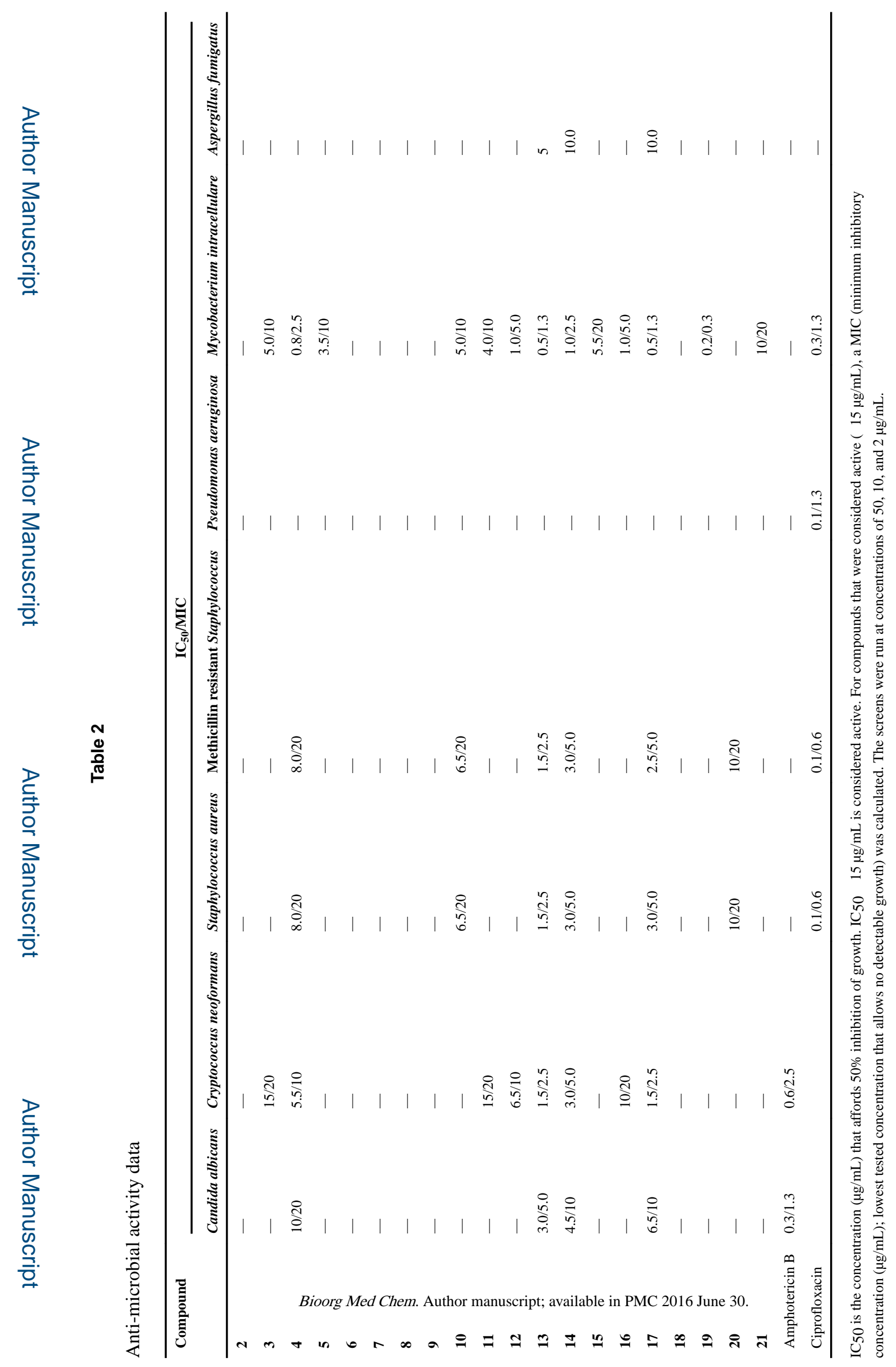




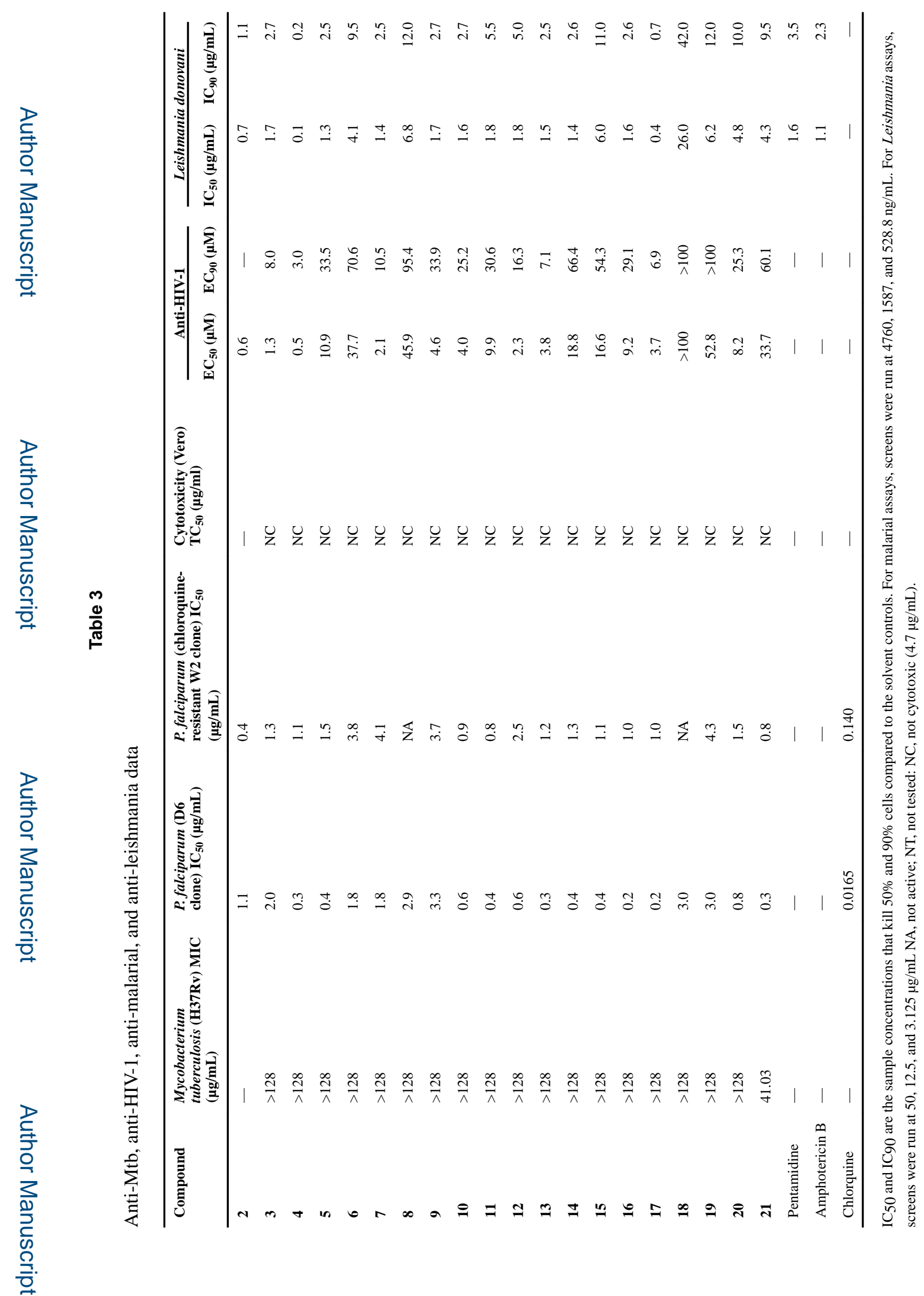

Bioorg Med Chem. Author manuscript; available in PMC 2016 June 30. 


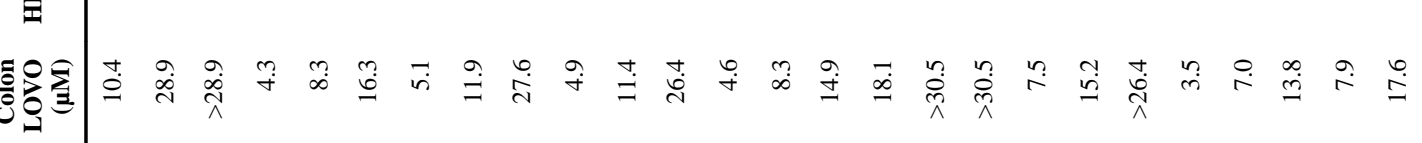

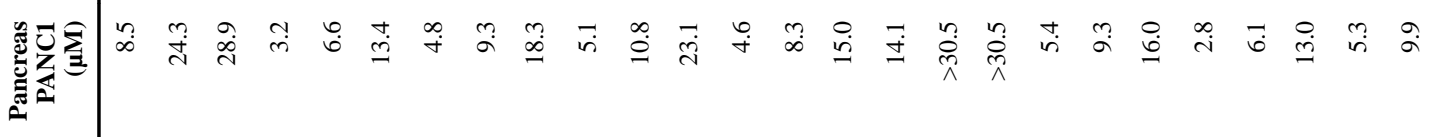

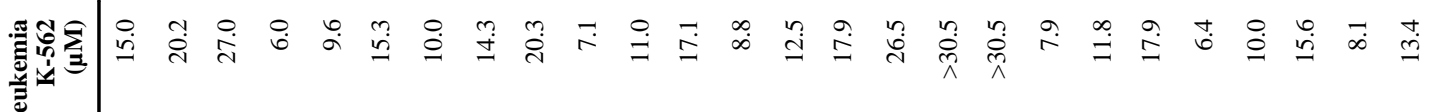

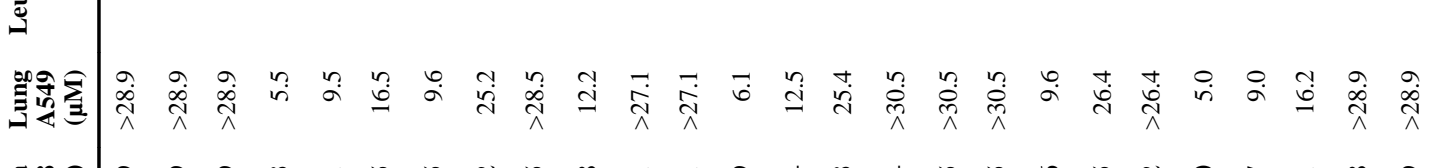

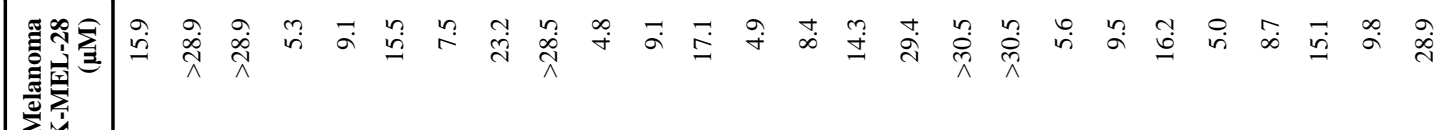

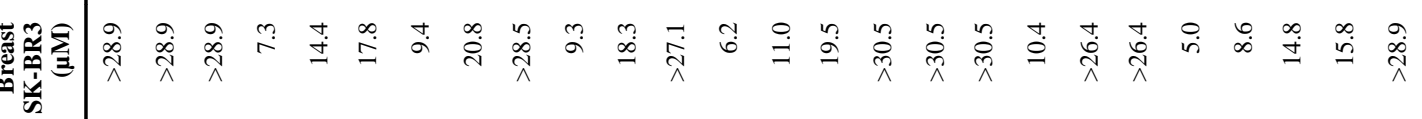

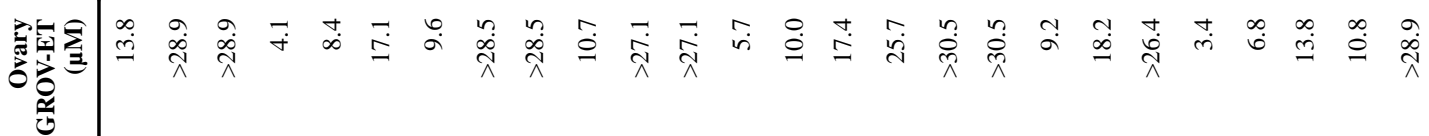

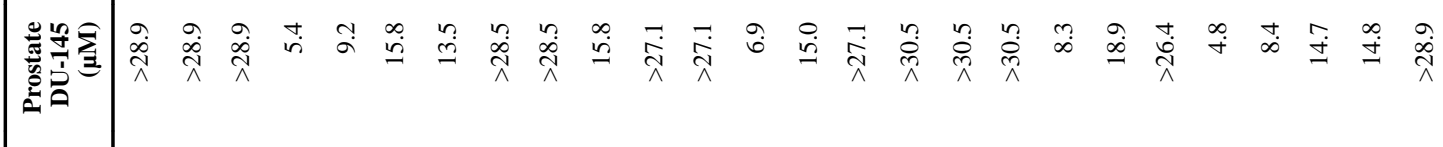

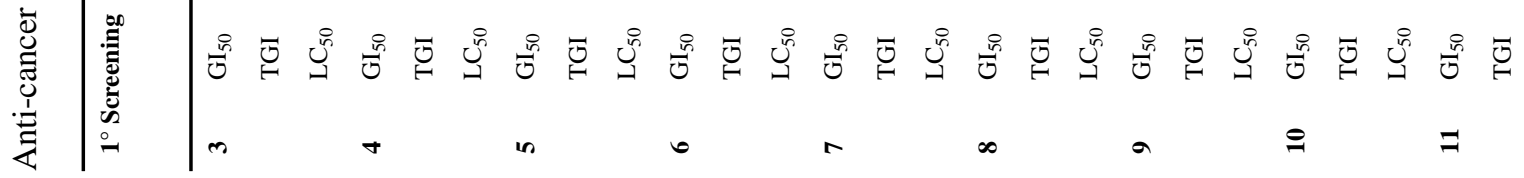




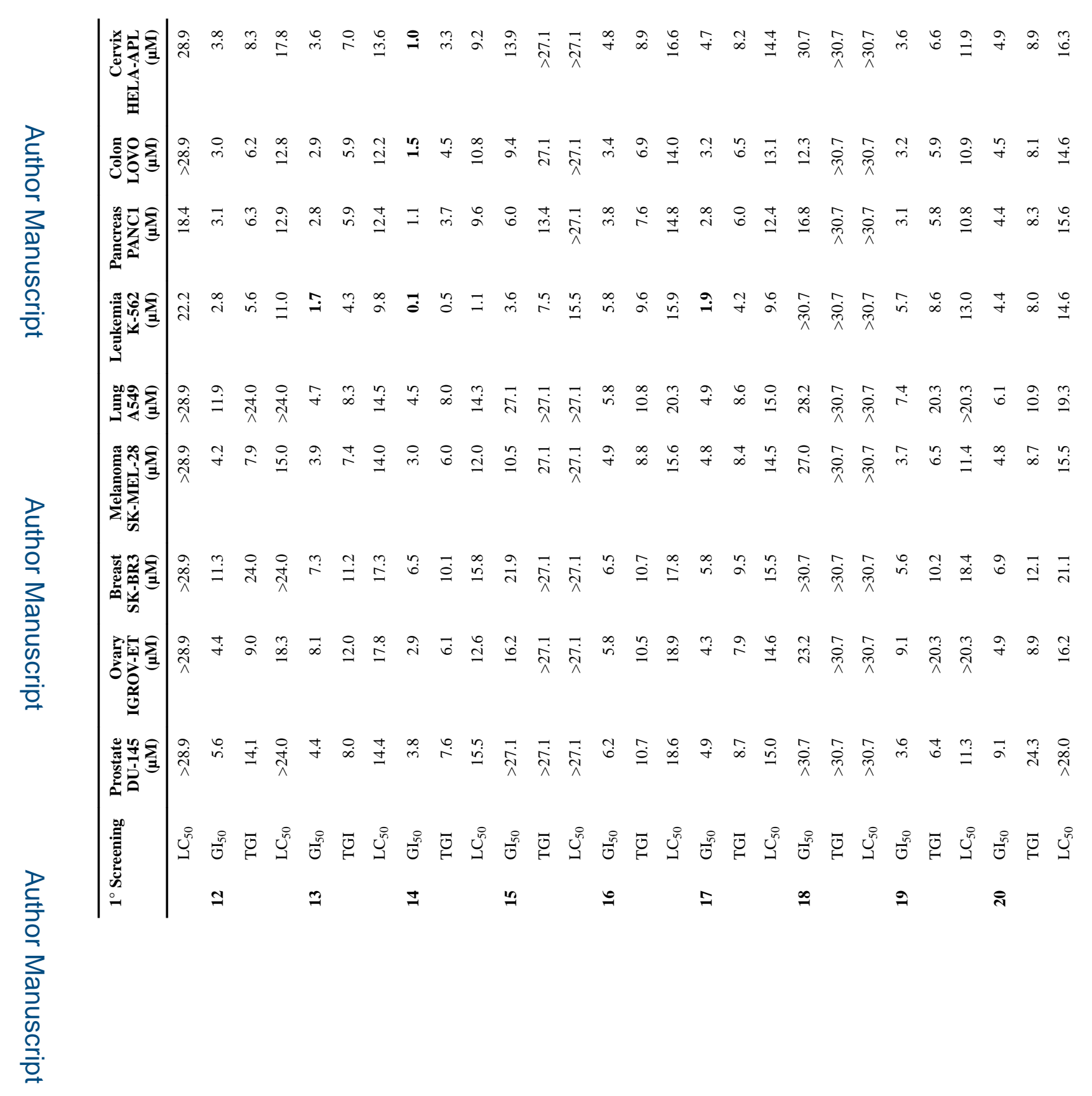

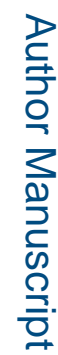




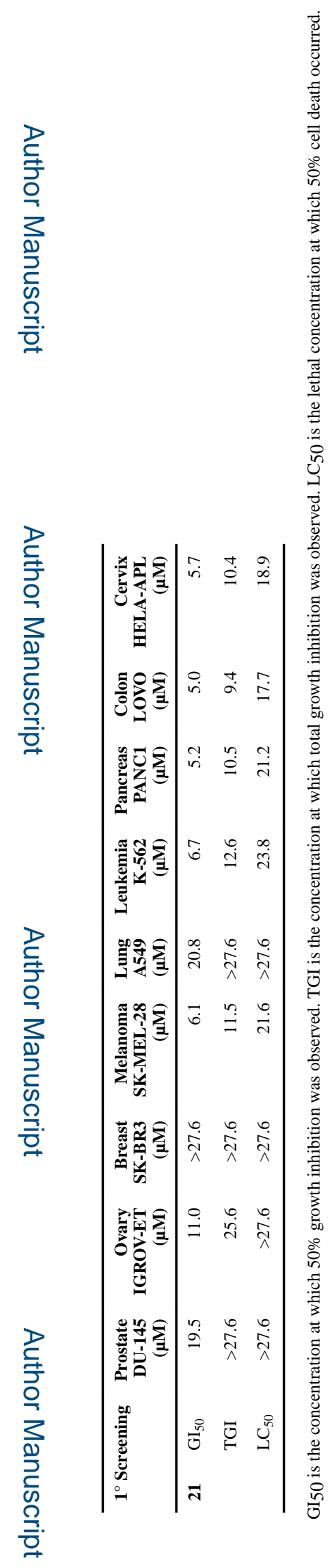




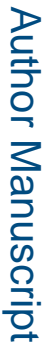

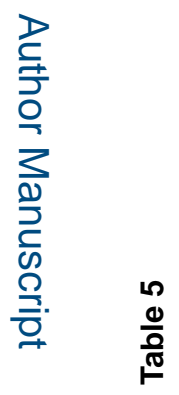

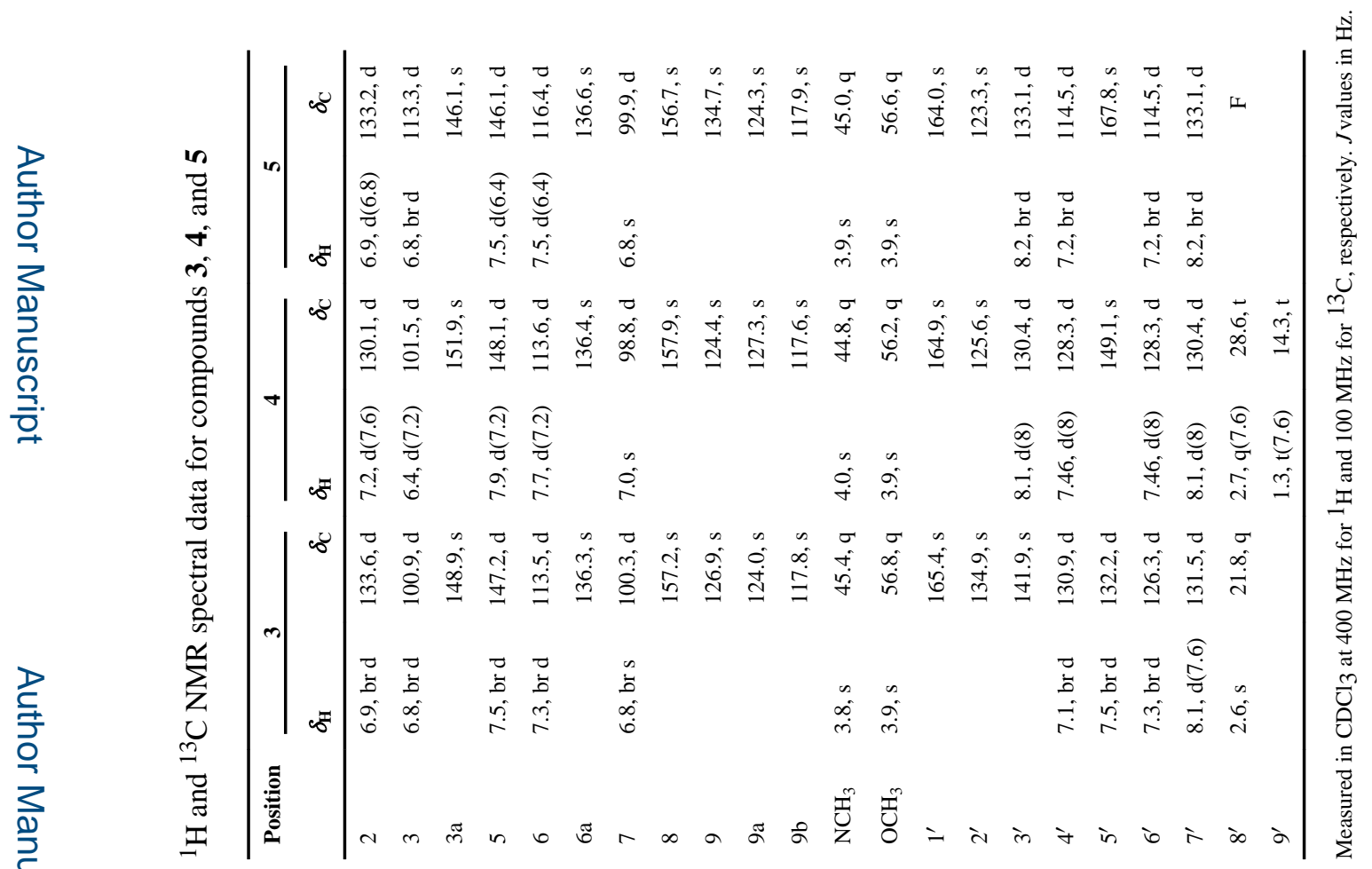

Bioorg Med Chem. Author manuscript; available in PMC 2016 June 30. 

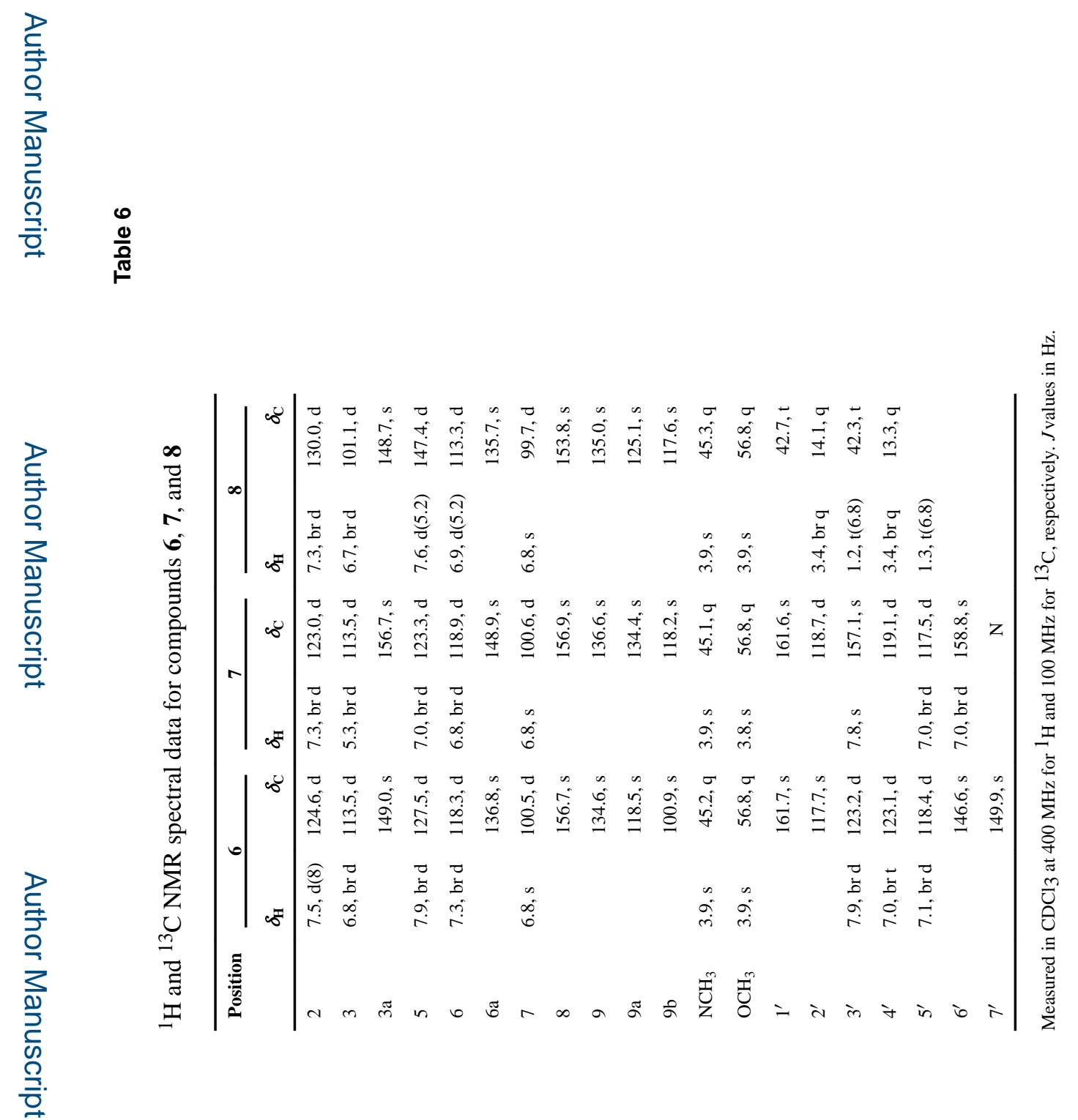

Bioorg Med Chem. Author manuscript; available in PMC 2016 June 30. 

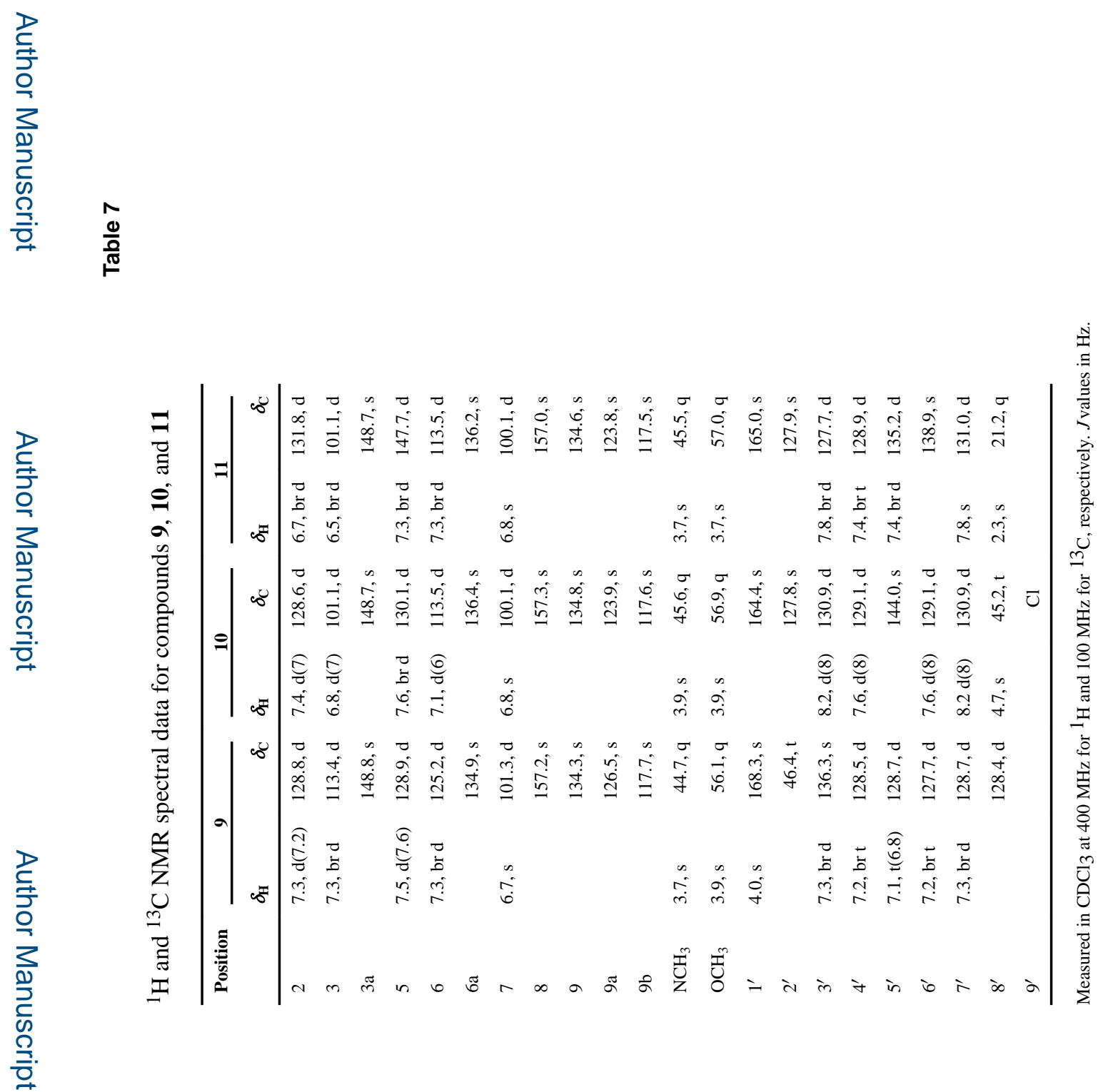

Bioorg Med Chem. Author manuscript; available in PMC 2016 June 30. 

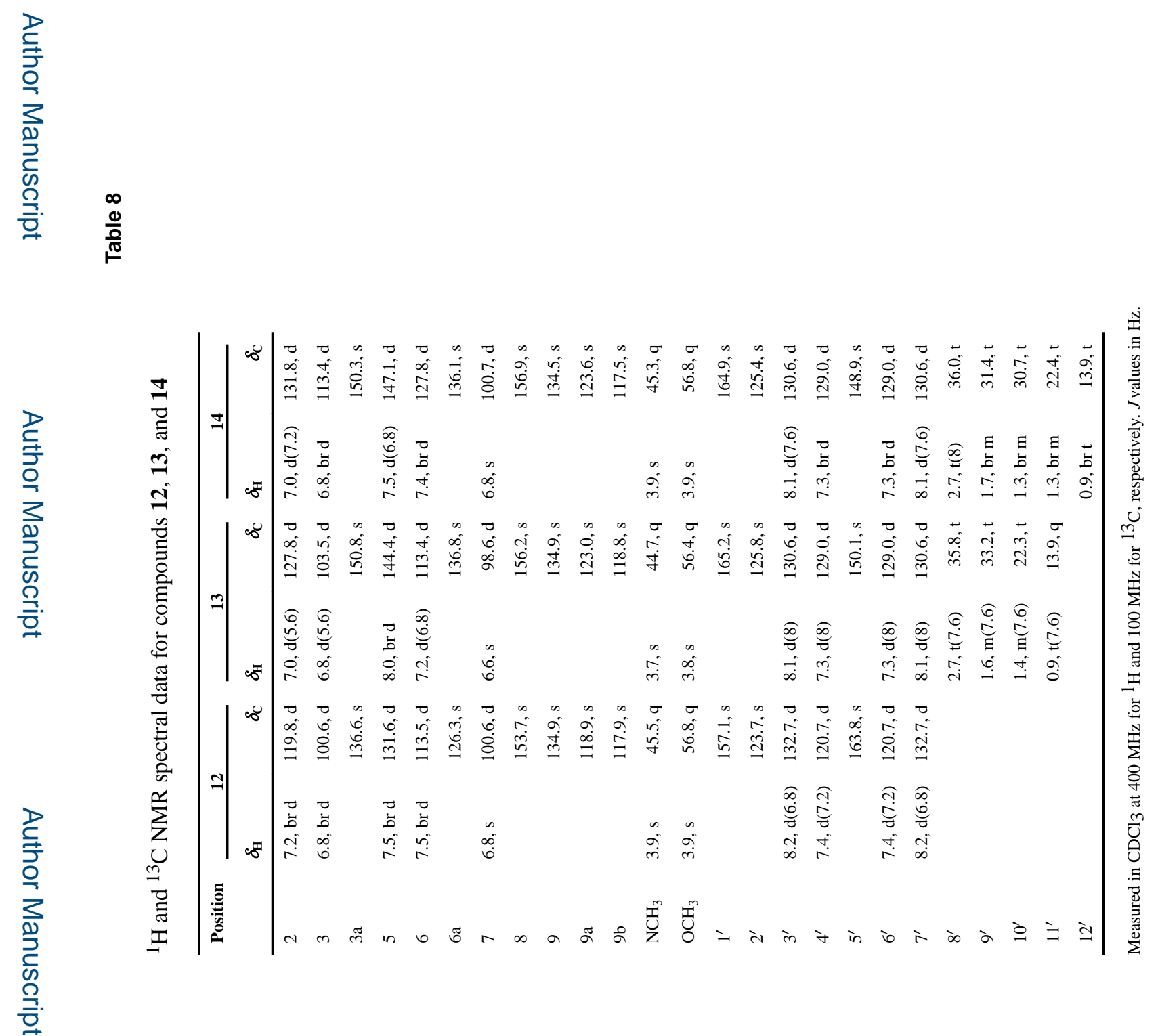

Bioorg Med Chem. Author manuscript; available in PMC 2016 June 30. 

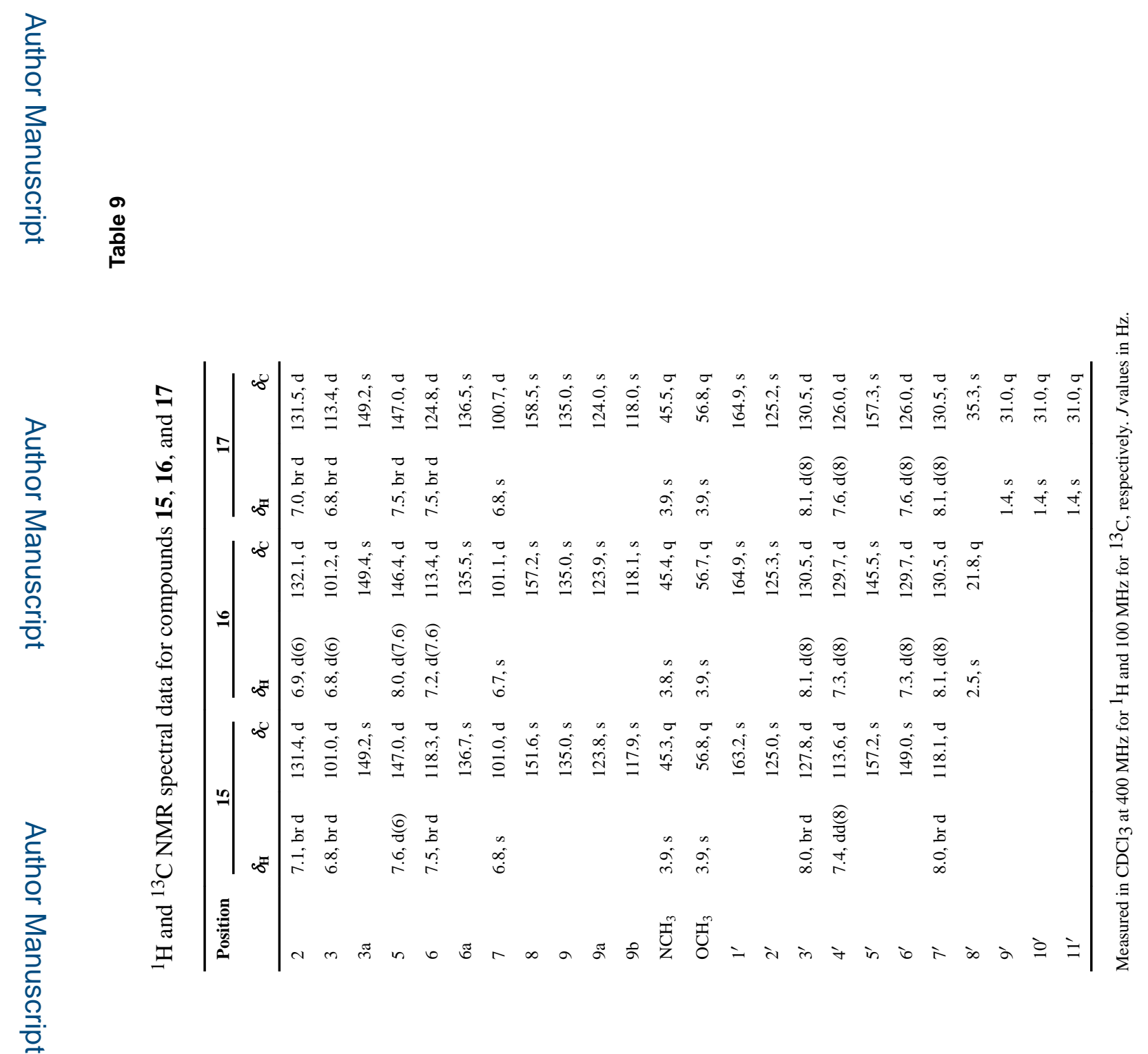

Bioorg Med Chem. Author manuscript; available in PMC 2016 June 30. 

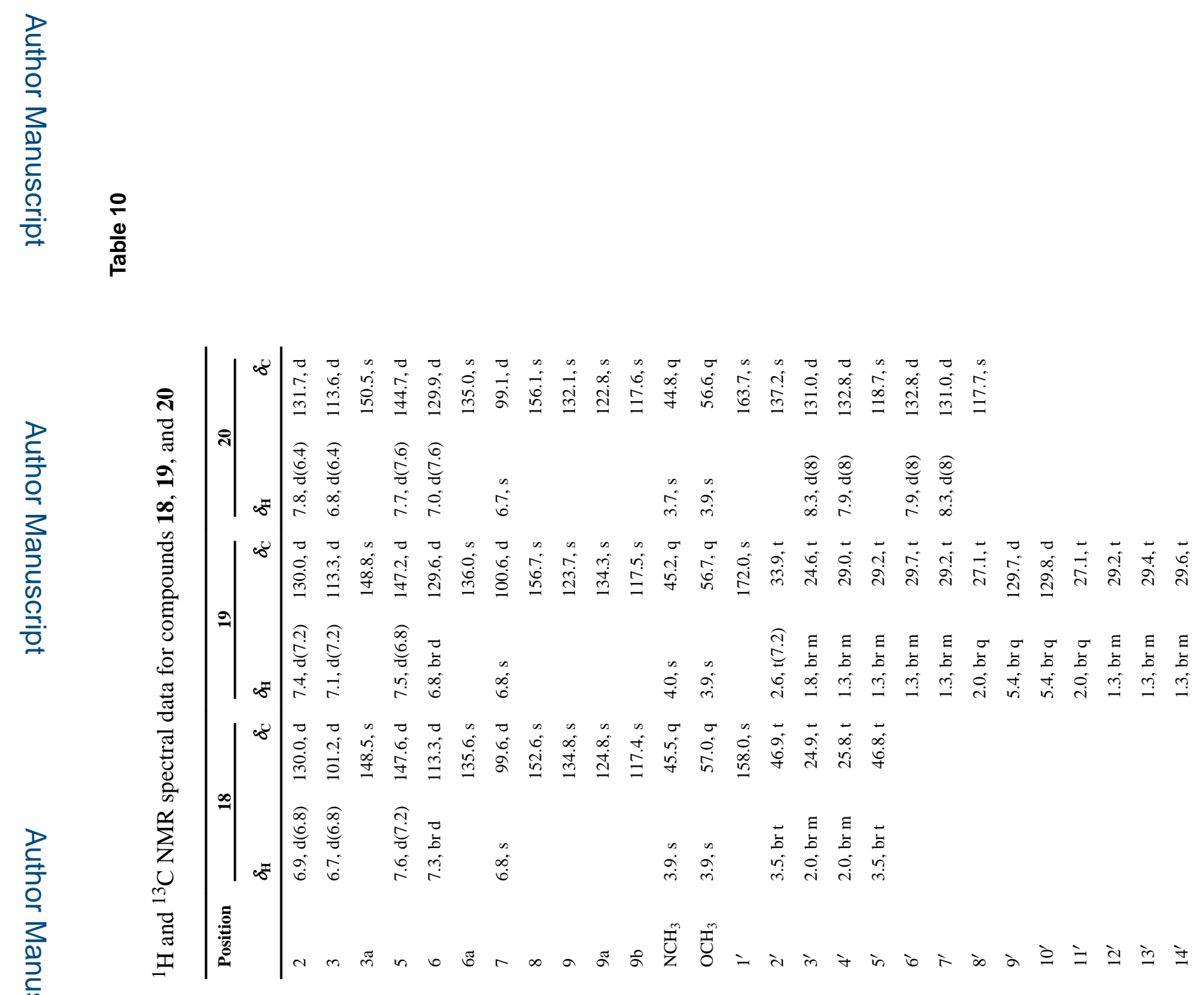

Bioorg Med Chem. Author manuscript; available in PMC 2016 June 30. 


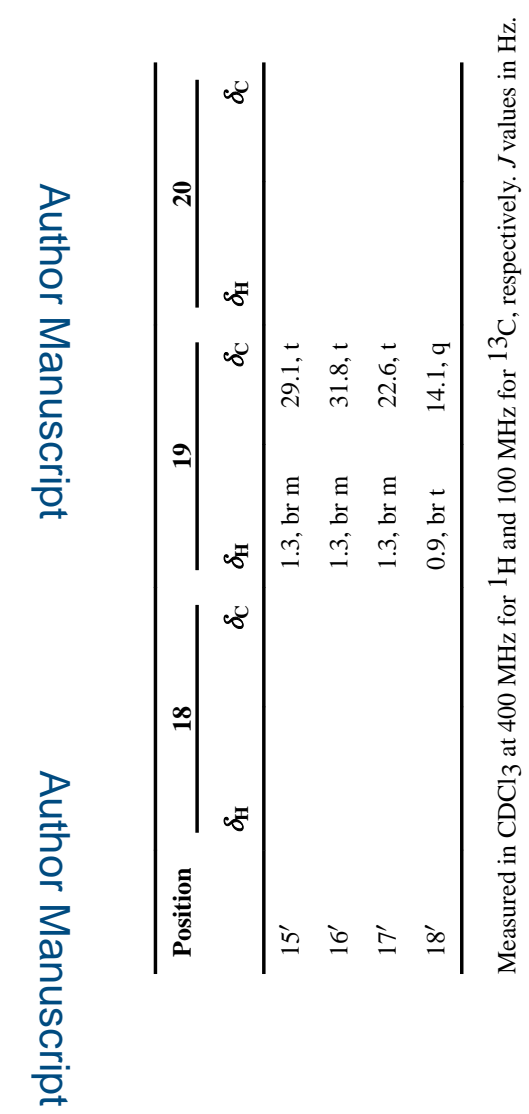

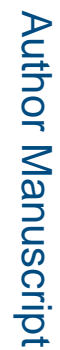

를 
Table 11

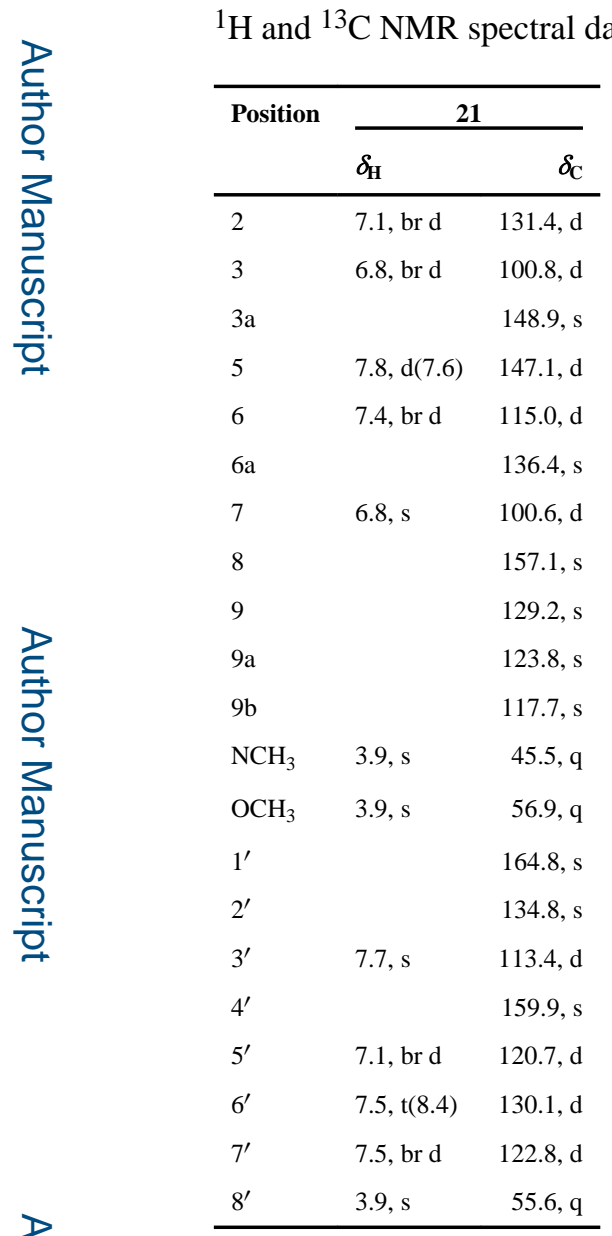

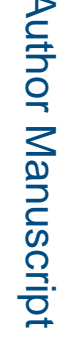

Measured in $\mathrm{CDCl}_{3}$ at $400 \mathrm{MHz}$ for ${ }^{1} \mathrm{H}$ and $100 \mathrm{MHz}$ for ${ }^{13} \mathrm{C}$, respectively. $J$ values in $\mathrm{Hz}$. 